\title{
Interior Materials and Colors for Study Room Comfort
}

\author{
Alexandra Ivanova \\ Associate Professor, Doctor of Art Sciences, \\ Department of Architecture, High School for Building \\ construction “Ljuben Karavelov", Sofia, Bulgaria
}

Teordor Roshavelov

Assistant Professor, Doctor of constructional Sciences, Department of Architecture, High School for Building construction “Ljuben Karavelov", Sofia, Bulgaria

Ivanka Marinova

Doctor of Architectural Sciences

Ivanka Dobreva

Doctor of constructional Sciences

Nikolai Alexandrov

PhD student in constructional Sciences

\begin{abstract}
The article studies the properties of interior color schemes and finishing materials in order to find optimal combination for improving indoor conditions in higher education study room and to contribute to better educational process. Optical, physical, physiological and emotional properties of colors and materials are compared to living and study requirements in the context of their complexity. Recommendations for appropriate combinations of finishing materials and colors are given.
\end{abstract}

Keywords: higher education, interior color, interior material, study room, living comfort

\section{Introduction}

Higher education study is a complex process. Existing facilities rarely meet the contemporary comfort requirements and are not designed toward providing conditions supporting properly the multiple tasks of study process. Prospects for using the research results are creating color-material combinations for high education study room in order to improve study process for both students and lectors. 
The goal of this research is to define optimal combinations of interior covering materials and color schemes to provide alternative solution to interior comfort requirements regarding study process in higher educational facility in Sofia, Bulgaria. In the article study room exploration period and color design are analyzed. Optical, physical, physiological and emotional properties of colors and materials are studied regarding the way they alter human perception about the space and its elements.

Researches on color in architecture date from the very early written sources up to nowadays [16]. Studies on color impact upon temperature perception date back from 60 -ies of 20-th century [8]. Studies of interior materials imoact upon inhabitants date back to the 90 -ies of 20 -th century [19]. Studies about contemporary education specifics and new kind of space organization it requires, including comfort levels. Researches about finishing materials study the way they improve interior thermal, light and acoustic comfort, regardless of color scheme.

Color studies can be categorized by their duration, by the way they are held, by the studied subject, by selected target group, by studied activities and by the results.

There are few studies of the role of study room color-material combination as a means to solve the complex task improving indoor comfort and study and creativity process as well.

\section{Study room analysis}

\subsection{Higher educational process changes}

Higher education system is undergoing qualitative changes affect the students and the process of studying [1]. Results of the process are to be specialists technically and emotionally intelligent [3]. Though technologies development raises a discussion about necessity of physical space for studying process, there are solid arguments in favor of physical presence [4]. However great part of higher education facilities is built in earlier periods and organized for different educational system and processes. Meeting the new study process requirements raises the need for new kinds of spaces and organization. Based upon the trend for sustainable development outlining resource and economical shortages new buildings are not always possible solution [6]. Revitalization and modernization of existing ones becomes a priority [7].

Two main groups of contemporary requirements can be identified. Building constructions are expected to meet contemporary requirements for energy efficiency, environmental-friendly materials and technology-supporting qualities.

Study environment is expected to provide the necessary conditions for the ongoing processes including thermal comfort, air quality, light comfort, acoustic comfort, learning and information assimilation, problem solving, recreating and socializing. 
In addition to conventional approaches, alternative developments are also considered. Such is the application of colors and materials according to their optical, physical, physiological and emotional properties.

\subsection{Higher education study room analysis}

Permanent inhabitants are students ( $20+$ persons) average aged about 22 years.

Temporary residents re lecturers and assistants, time of stay and age vary.

Activities vary from lecturing, practical exercises, self training to socializing and recreating.

The combination of various activities and occupants requires combined approach towards improved working and study environment [5] and meeting inhabitants' preferences [6]. Significant amount of objective and subjective factors are to be taken into account in order to create optimal comfort.

Period of active use is 2-8 hours per day, average 5 days in a week, from September to June. No or seldom incident use in July and August.

Fig.1 displays that periods of active visiting of study room coincides with weather periods of lower temperatures and predominant cloudy.

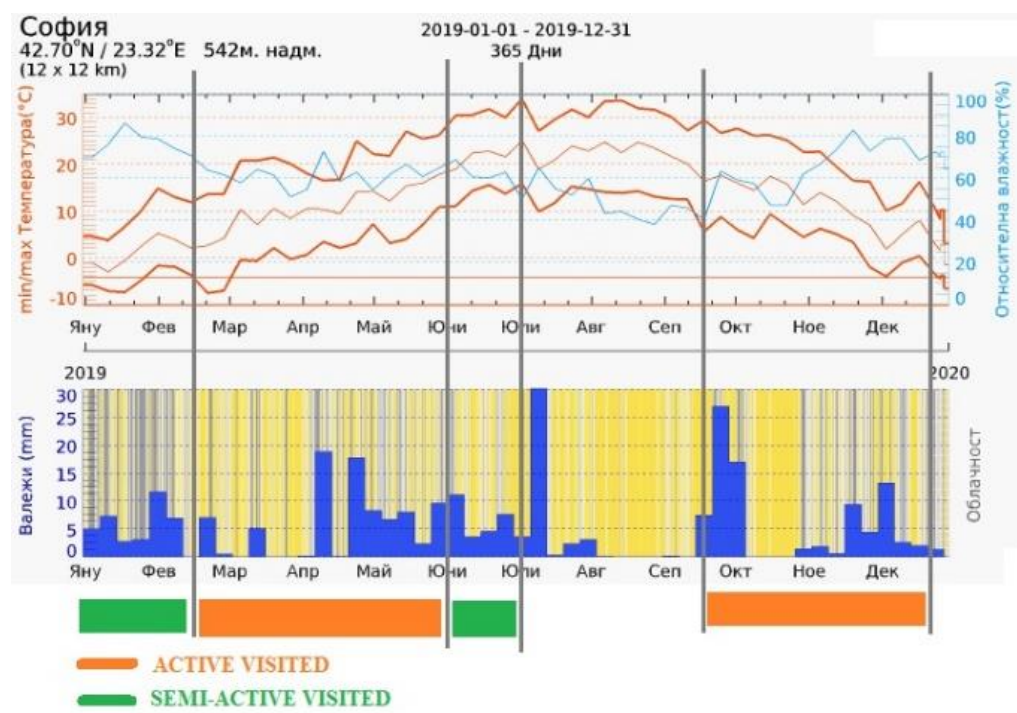

Fig.1 Monthly visiting activity compared to weather data for a year period (data source: https://www.meteoblue.com/bg/времето/historyclimate/weatherarchive/София_re publika-bulgariya_727011)

$83 \%$ of the inhabitants reveals admit that study rooms "feel" cold and dark more than half of the time. Conclusion is that priority should be given to improving heat and light comfort. 
Since the building is insulated with $10 \mathrm{~cm}$ XPS, colors and materials should be considered as a means to alternate heat and light comfort perception of the inhabitants.

\subsection{Higher education study room color design analysis}

The comparison illustrated in table 1 reveals that the application of colors according to those properties that contribute to increasing the comfort of the occupants does not appear in the traditional color scheme of a study room.

Table 1. Comparison of traditional study room colour design with modern requirements

\begin{tabular}{ll}
\hline Modern requirements & Traditional colour design \\
\hline $\begin{array}{l}\text { information about surrounding objects, } \\
\text { functional zones marking }\end{array}$ & $\begin{array}{l}\text { information about surrounding objects, } \\
\text { functional zones marking } \\
\text { aesthetic value }\end{array}$ \\
$\begin{array}{l}\text { symbolic meaning } \\
\text { according to the perceptions and preferences }\end{array}$ \\
$\begin{array}{l}\text { of inhabitants } \\
\text { visual supplementation and adjustment } \\
\text { of living environment characteristics }\end{array}$ \\
$\begin{array}{l}\text { light distribution and heat storage } \\
\text { physiological and psychological impact }\end{array}$ \\
$\begin{array}{l}\text { on the inhabitants } \\
\text { new technologies in covering materials }\end{array}$ \\
\hline
\end{tabular}

\subsection{Choosing higher education study room color scheme}

Colors influence light comfort perception through their physical properties to reflect or absorbed light. Centripetal and centrifugal color properties alternate the way space and its elements are perceived [13] (tab.2).

Table 2. Optical properties of colours

\begin{tabular}{|c|c|c|c|c|c|}
\hline \multirow[b]{2}{*}{ color } & \multirow{2}{*}{$\begin{array}{l}\% \text { reflected } \\
\text { visible light }\end{array}$} & \multicolumn{4}{|c|}{ Elements' perciving } \\
\hline & & Zooms in & $\begin{array}{l}\text { Zooms } \\
\text { out }\end{array}$ & sharpens & smoothes \\
\hline white & 90 & & & $\mathrm{x}$ & \\
\hline yellow & $50-70$ & $\mathrm{x}$ & & $\mathrm{x}$ & \\
\hline orange, red, brown & $20-40$ & $\mathrm{x}$ & & $\mathrm{x}$ & \\
\hline green, blue, purple & $15-25$ & & $\mathrm{x}$ & & $\mathrm{x}$ \\
\hline black & 10 & $\mathrm{x}$ & & & $\mathrm{x}$ \\
\hline
\end{tabular}

Physiological effects of colors include the stimulation of certain processes in human body [8], [10]. Emotional impact on colors is related to a subjective comfort criteria trough variety of associations color tones and shades induce [15]. 
Table 3. Psychological aspects of colour design in study rooms

\begin{tabular}{|c|c|c|c|c|c|c|c|c|c|c|c|c|}
\hline \multirow[t]{2}{*}{$\begin{array}{l}\text { Colou } \\
\mathrm{r}\end{array}$} & \multicolumn{2}{|c|}{$\begin{array}{l}\text { Thermal } \\
\text { perceiving }\end{array}$} & \multicolumn{2}{|c|}{$\begin{array}{l}\text { Light } \\
\text { perceiving }\end{array}$} & \multicolumn{2}{|c|}{$\begin{array}{l}\text { Acoustic } \\
\text { perceivin } \\
\mathrm{g}\end{array}$} & \multicolumn{2}{|c|}{$\begin{array}{l}\text { Space } \\
\text { perceiving }\end{array}$} & \multicolumn{2}{|c|}{$\begin{array}{l}\text { Study } \\
\text { activities }\end{array}$} & \multicolumn{2}{|c|}{ Mood } \\
\hline & $\begin{array}{l}\text { war } \\
\mathrm{m}\end{array}$ & $\begin{array}{l}\text { col } \\
\mathrm{d}\end{array}$ & $\begin{array}{l}\text { ligh } \\
t\end{array}$ & $\begin{array}{l}\text { dar } \\
\mathrm{k}\end{array}$ & $\begin{array}{l}\text { goo } \\
\text { d }\end{array}$ & $\begin{array}{l}\text { ba } \\
d\end{array}$ & $\begin{array}{l}\text { broadl } \\
\text { y }\end{array}$ & $\begin{array}{l}\text { narro } \\
\mathrm{w}\end{array}$ & $\begin{array}{l}\text { focu } \\
\text { s }\end{array}$ & $\begin{array}{l}\text { distra } \\
\text { ct }\end{array}$ & $\begin{array}{l}\text { goo } \\
\text { d }\end{array}$ & $\begin{array}{l}\text { ba } \\
d\end{array}$ \\
\hline white & & $\mathrm{x}$ & $\mathrm{x}$ & & & & $\mathrm{x}$ & & & & & \\
\hline $\begin{array}{l}\text { yello } \\
\text { w }\end{array}$ & $\mathrm{x}$ & & $\mathrm{x}$ & & $\mathrm{x}$ & & $\mathrm{x}$ & & $\mathrm{X}$ & & $\mathrm{x}$ & \\
\hline $\begin{array}{l}\text { orang } \\
\text { e }\end{array}$ & $\mathrm{x}$ & & $\mathrm{x}$ & & $\mathrm{x}$ & & $\mathrm{x}$ & & & $\mathrm{x}$ & $\mathrm{x}$ & \\
\hline red & $\mathrm{x}$ & & & $\mathrm{x}$ & & & & $\mathrm{x}$ & & $\mathrm{x}$ & & $\mathrm{x}$ \\
\hline pink & $\mathrm{x}$ & & $\mathrm{x}$ & & & & & & & $\mathrm{x}$ & $\mathrm{x}$ & \\
\hline $\begin{array}{l}\text { brow } \\
\text { n }\end{array}$ & $\mathrm{x}$ & & & $\mathrm{x}$ & & $\mathrm{x}$ & & $\mathrm{x}$ & & $\mathrm{X}$ & & $\mathrm{x}$ \\
\hline green & & $\mathrm{x}$ & & & & $\mathrm{x}$ & & $\mathrm{x}$ & $\mathrm{x}$ & & $\mathrm{x}$ & \\
\hline blue & & $\mathrm{x}$ & & $\mathrm{x}$ & & $\mathrm{x}$ & & $\mathrm{x}$ & $\mathrm{x}$ & & $\mathrm{x}$ & \\
\hline violet & & $\mathrm{x}$ & & $\mathrm{x}$ & & $\mathrm{x}$ & & $\mathrm{x}$ & $\mathrm{x}$ & & & $\mathrm{x}$ \\
\hline black & & & & $\mathrm{x}$ & & $\mathrm{x}$ & & $\mathrm{x}$ & & $\mathrm{x}$ & & $\mathrm{x}$ \\
\hline
\end{tabular}

\subsection{Choosing higher education study room finishing materials}

Studies reveal that according to the way they have been processed, materials can lead to lowered blood pressure (wood) [17], can affect air quality perception (wood, cotton, corian) [18], can moderate air humidity and therefore impact air temperature due to exchange of latent heat and also have antibacterial effect, improves acoustic, has positive emotional and tactical effect (wood) [19].

\section{Conclusions}

When creating material-color design of study room the complexity of activities and inhabitants should be considered. The space should be zoned trough color and material signatures to several functional zones.

Colors to alternate thermal and light comfort perception are light shades of red, orange and yellow.

Colors to activate study process are yellow and purple.

Colors to support problem solving and creativity are red, orange and purple.

Colors to improve student-lector communication process and socialization are yellow and orange.

Materials to improve air and acoustic comfort perception are natural-based materials with minimum procession as wood, cotton and corian. Wood also improves physiological and emotional comfort. 
Optimal combinations would be wooden-based covering elements with saturated shades of red, orange, yellow and purple.

\section{Acknowledgments}

The studies in this report are funded by science-research project №11, order № 256 / 27.05.2020. The authors express their gratitude to VSU "Lyuben Karavelov", Bulgaria.

\section{References}

[1] D. Eastcott, S. Brand, N. Wynne, L. Millard, Challenges in Teaching and Learning in Higher Education, (In book: Challenges in Teaching and Learning in Higher Education, Chapter: Fostering Innovation and Embedding Change, Publisher: University of Aveiro/Portugal and SLO/NetherlandsEditors: V. Gil, I Alarcao, H Hooghoff), September 2004

[2] F. Fatkullina, E. Morozkina, A. Suleimanova, Modern Higher Education: Problems and Perspectives, ScienceDirect: Procedia - Social and Behavioral Sciences, 2015 p-p $571-577$

[3] Goreva GГорева Г. 2016 Educational reference book on the subject of color science and color (Minsk: Belarusian State University) p 36

[4] Hettiarachchi and Emmanuel R 2017 Colour as a psychological agent to manipulate perceived indoor thermal environment for low energy design ; cases implemented in Sri Lanka (Scotland: Passive Low Energy Architecture (PLEA) - Design to Thrive Conference)

[5] Hohmann T 2006 New Aspects of Library Design (Netherlands: LIBER Utrecht University Library Open Access Journals)

[6] Ingrid Senitkova, Interior Materials Combination and Perceived Indoor Air Quality, 2019, MATEC Web of Conferences 279:0300, DOI: 10.1051/matecconf/201927903001

[7] Jose Luis Caivano, The research on color in architecture: Brief history, current developments and possible future, Color Research \& Application 31(4):350 363,2006

[8] K.Hamburgerab H. Priorb V. Sarrisb L. Spillmanna Filling-in with colour: Different modes of surface completion Vision Research Volume 46, Issues 6-7, March 2006, Pages 1129-1138

[9] M. Bittencourt, Sustainability assessment of the university buildings : an application of a multi-criteria and multi-actor tool to help the decision-making process, $\mathrm{PhD}$ thesis, Université de Versailles-Saint-Quentin-en-Yvelines, 2017

[10] M. Costa1, S. Frumento, M. Nese I. Predieri, Interior Color and Psychological Functioning in a University Residence Hall, Frontiers in Psychology, 2018 
[11] S. Bennett, First Questions for Designing Higher Education Learning Spaces, The Journal of Academic Librarianship, Volume 33, Number 1, pages 14-26, December 2006

[12] Sun M., Nakashima T., Yoshimura Y., Shimizu K., Effects and interaction of different interior material treatment and personal preference on psychological and physiological responses in living environment, 2020, Journal of Wood Science 66(63), DOI: 10.1186/s10086-020-01910-2

[13] T. E. Alapieti, R. Mikkola, P. Pasanen, H. Salonen, The influence of wooden interior materials on indoor environment: a review, July 2020European Journal of Wood and Wood Products 78(1), DOI: 10.1007/s00107-020-01532$\mathrm{x}$

[14] Winzen, J, Albers, F. \& Marggraf-Micheel, C. The Influence of coloured light in the air-craft cabin on passenger thermal comfort. Lighting Research and Technology, 0, 1-11 (online first publication; DOl: 10.1177/1477153513484028), 2013 